\title{
The Development and Demise of Protestant Provincial Schools in Inner Austria
}

\section{T. Vidmar}

For citation: Vidmar T. The Development and the Demise of Protestant Provincial Schools in Inner Austria. Vestnik of Saint Petersburg University. History, 2020, vol. 65, issue 4, pp. 1147-1161.

https://doi.org/10.21638/11701/spbu02.2020.408

This paper analyzes and clarifies motivations and reasons for a short but intensive development of the secondary level of schooling followed by a sudden end, especially of the so-called Provincial schools, in three Inner Austrian lands (Carniola, Styria and Carinthia) in the $16^{\text {th }}$ century. The situation regarding the organization of schooling in the $16^{\text {th }}$ century was incomparable with the situation in the states headed by the Protestant rulers. Nevertheless, a type of Protestant gymnasium emerged here, which was called Provincial school (Landschaftsschule) and which also required some prior elementary knowledge for enrollment. For each of the three lands - Carniola, Carinthia and Styria - the establishment of the Provincial School was the first actual opportunity for the foundation of a central institution providing not only elementary knowledge, but also higher levels of education partly comparable to the curricula of the faculties of arts. Unfortunately, at the end of the $16^{\text {th }}$ century, the development of the Provincial Schools was forcibly stopped. The article is based upon a thorough analysis and comparison of the relevant primary and secondary sources (in Latin, Slovene, German and English). The results show that all three school underwent similar phases of development and the same sudden termination, despite different inner circumstances, material foundations and time frame. In any case, the three Provincial Schools played an important part in the development of humanistic education on the territory of modern Republic of Slovenia and the Republic of Austria.

Keywords: Provincial School, Protestant gymnasium, Styria, Carniola, Carinthia, secondary education, Protestantism, Reformation.

\section{Развитие и упадок протестантских провинциальных школ во Внутренней Австрии}

\section{T. Видмар}

Для цитирования: Vidmar T. Development and the Demise of Protestant Provincial Schools in Inner Austria // Вестник Санкт-Петербургского университета. История. 2020. Т.65. Вып. 4. C. 1147-1161. https://doi.org/10.21638/11701/spbu02.2020.408

В статье анализируются и разъясняются мотивы и причины непродолжительного, но интенсивного, внезапно прекратившегося развития среднего школьного образования, особенно так называемых провинциальных школ, на трех землях Внутренней Ав-

Tadej Vidmar - PhD (Pedagogy), Associate Professor, University of Ljubljana, 2, Aškerčeva ulica, Ljubljana, 1000, Slovenia; tadej.vidmar@ff.uni-lj.si

Тадей Видмар - д-р пед. наук, доц., Люблянский университет, Словения, 1000, Любляна, Ашкерчева ул., 2; tadej.vidmar@ff.uni-lj.si

(C) St. Petersburg State University, 2020 
стрии (Карниола, Штирия и Каринтия) в XVI в. Ситуация с организацией школьного образования в то время была несопоставима с положением в государствах, управляемых протестантскими правителями. Тем не менее здесь возник тип протестантской гимназии, которая получила название «провинциальная школа» (Landschaftsschule) и которая также требовала некоторых элементарных знаний для поступления. Для каждой из трех земель - Карниолы, Каринтии и Штирии - создание провинциальной школы было первой реальной возможностью для основания центрального учреждения, обеспечивающего не только базовые знания, но и более высокие уровни образования, которые частично были сопоставимы с учебными программами факультетов искусств. К сожалению, в конце XVI в. развитие провинциальных школ было остановлено. Статья написана на основе тщательного анализа и сравнения соответствующих первичных и вторичных источников (на латинском, словенском, немецком и английском языках). Результаты показывают, что все три школы прошли схожие фазы роста и пережили их одинаковое внезапное окончание, несмотря на разные внутренние обстоятельства, материальную основу и временные рамки. В любом случае три провинциальные школы сыграли важную роль в становлении гуманистического образования на территории, где сегодня находятся Республика Словения и Республика Австрия.

Ключевые слова: провинциальная школа, протестантская гимназия, Штирия, Карниола, Каринтия, среднее образование, протестантизм, Реформация.

\section{Introduction}

It is necessary to outline some principal starting points from which Protestant theorists as well as practitioners of Protestant pedagogy derived their ideas in order to better understand the basics of the development of the Protestant school system, especially the secondary school-system in the three Inner Austrian lands. One of the most important and critical consequences of the Reformation in the field of schooling was the beginning of the process, which lasted for centuries, when schooling and education gradually came under the control of the state. This process began with the promulgating and implementing the Church Ordinances (Kirchenordnungen) and corresponding School Ordinances (Schulordnungen) issued by secular authorities. The sovereigns, who converted from Catholicism to Protestantism, set themselves a goal of establishing the new church as soon as possible and a school organization. The emphasis of these efforts was on the secondary level of education ${ }^{1}$.

This action was made politically possible after the decision of the Diet of Speyer in 1526, according to which the religion of the land was determined by the faith of its ruler (cuius regio, eius religio) $^{2}$. The sovereigns issued these school regulations primarily in their function of the highest local religious authorities, which they became after the adoption and implementation of the Reformation in their countries. Of course, regional rulers entrusted their regional churches with the daily supervision of the education and schooling.

In the $16^{\text {th }}$ century, there was still no fixed differentiation between the secondary school and the university (i.e. its faculty of arts (facultas artium)), as there was still no fixed difference in teaching. The biggest dissimilarity between an excellent secondary school and the university was only in the legal position of both. The university was the

1 Vidmar T. Nastajanje novoveške stopenjske šolske strukture. Ljubljana, 2005.

${ }^{2}$ Loserth J. Die protestantischen Schulen der Steiermark im sechzehnten Jahrhundert // Monumenta Germaniae Paedagogica: in 62 Bdn. Bd. LV. Berlin, 1916; Vidmar T. Das protestantische Schulwesen in Krain, in Kärnten und in der Steiermark. Klagenfurt, 2008. 
institution to which public authorities (either secular or ecclesiastical) gave the right to confer academic degrees and titles. Any institution that did not have this right could not be named "university" or presented itself as "university," even though it was just as "scientific" and provided the same high-quality teaching as the "real" university ${ }^{3}$.

In the three Inner Austrian hereditary lands (Carniola, Styria, and Carinthia), the situation regarding the organization of schooling in the $16^{\text {th }}$ century was incomparable with the situation in the states headed by the Protestant rulers. Nevertheless, a type of Protestant gymnasium emerged here, which was called Provincial school (Landschaftsschule) and which also required some prior elementary previous knowledge for enrollment ${ }^{4}$. The teaching staff at these schools was also not as "provincial" as it might appear because famous Protestant scholars, such as Nicodemus Frischlin in Ljubljana, Johannes Kepler and David Chytraeus in Graz and Hieronymus Megiser in Klagenfurt worked at these schools.

\section{An outline of the educational situation in Inner Austrian lands in the mid- $16^{\text {th }}$ century}

The tension between the ruling Habsburg dynasty, who were Catholic, and the Provincial Estates, who - from the mid-16 ${ }^{\text {th }}$ century onwards - were mostly Protestant, led to a competition between Catholic and Protestant schools in Inner Austrian lands. Even earlier, the Habsburg local sovereigns (Landesfürsten) - in their places of residence founded Jesuit colleges, the Estates set up their own schools, which - in the initial period of their existence (around the mid- $16^{\text {th }}$ century) - had the character of noble Provincial schools (kind of knightly academies), and were later turned into Protestant secondary schools. Those schools tried to prepare young people for university studies (mostly abroad in Protestant countries), and possibly to shorten the time of their education ${ }^{5}$. In their heyday - between the 1570s and 1580s - schools opened their doors to children of the middle classes as well, which met with even stronger opposition of the local Habsburg rulers. Against their will, but in accordance with the provisions of the Diet of Augsburg in 1555, they had to comply with the demands of the nobility for religious liberty and consequently for their own schools ${ }^{6}$. Three above-mentioned Inner Austrian lands followed common rules in the field of school organization, which were adopted in 1578, in Bruck an der Mur (so called Bruck (religious) Pacification).

As said above, the Protestant secondary schools - gymnasiums - were in Austria called Provincial schools (Landschaftsschulen) and were - in terms of their organization

3 Vidmar T. Nastajanje novoveške stopenjske šolske strukture; Engelbrecht H. Geschichte des österreichischen Bildungswesens - Erziehung und Unterricht auf dem Boden Österreichs: in 5 Bdn. Bd. 2: Das 16. und 17. Jahrhundert. Wien, 1982; Frijhoff W. Grundlagen // Geschichte der Universität in Europa: in 4 Bdn. Bd. II: Von der Reformation zur Französischen Revolution (1500-1800). 1996. P.53-102; Seifert A. Das höhere Schulwesen - Universitäten und Gymnasien // Handbuch der deutschen Bildungsgeschichte: in 6 Bdn. Bd. I: 15. bis 17. Jahrhundert - Von der Renaissance und der Reformation bis zum Ende der Glaubenskämpfe. München, 1996. P. 197-373.

${ }^{4}$ Vidmar T. Das protestantische Schulwesen in Krain, in Kärnten und in der Steiermark; Baum W. Kollegium, Lyzeum, Gymnasium. Vom "Collegium Sapientiae et Pietatis" zum Bundesgymnasium Völkermarkter Ring, Klagenfurt. Die Geschichte des ältesten Gymnasiums Österreichs. Klagenfurt, 1991; Engelbrecht $H$. Geschichte des österreichischen Bildungswesens...

${ }_{5}$ Vidmar T. Nastajanje novoveške stopenjske šolske strukture; Engelbrecht H. Geschichte des österreichischen Bildungswesens...

${ }^{6}$ Vidmar T. Das protestantische Schulwesen in Krain, in Kärnten und in der Steiermark. 
and programs - comparable to the German State schools (Landesschulen); they differed mainly in ways of financing ${ }^{7}$. The most important Provincial school in the Habsburg lands was the one in Graz, Styria. With its organization and structure, the Graz Provincial School was the model for other Provincial schools in Austria, but none of them ever achieved similar fame and importance ${ }^{8}$. In 1577, Styria opened another school in Judenburg, in 1586; Carinthia founded one in Klagenfurt in 1563; Carniola set up one in Ljubljana; and in 1574, a school was established in Linz, Upper Austria; in Vienna a Provincial school existed from 1576 onwards. In 1580, the local Habsburg sovereigns banned the children of the middle classes from attending school, which at the same time marked the beginning of the end of Provincial schools as the ban cut off a large and important share of pupils. The next decade was marked by the banishment of Protestant theologians and educators?

Protestants had considerable difficulty in developing and maintaining their schools in lands where local rulers were not of the Augsburg Confession. In the lands where the territorial sovereign was a Catholic and members of the Estates had a Protestant majority, the entire responsibility for education lay with the Provincial Estates. This was the situation in all three Inner Austrian lands - Styria, Carinthia and Carniola. Protestants were active in all three, but they met with fierce opposition from the Habsburg rulers. Each of the three lands - as was customary - adopted its own Church Ordinance, which Lutherans had to comply with. Part of every Church Ordinance was a School Ordinance, which specified the organization or structure of the educational system.

\section{Secondary Education in Carniola - Ljubljana}

\section{Church Ordinance 1564 - basis for the organization of the Ljubljana Provincial} School. In German Protestant lands church ordinances were issued by local rulers or sovereigns, who were also implementing them, while in Carniola (and other Inner Austrian hereditary lands), the local sovereign (during that period - Archduke Charles II Francis of Habsburg) in fact opposed the new Church organization. That is why the ordinance had to be issued and supported by the Provincial Estates ${ }^{10}$.

In Carniola, the superintendent of the Protestant Church, Primož Trubar (Primus Truber), wrote the Church Ordinance (Cerkovna ordninga) in $1564^{11}$. In composing it, he relied on the Church Ordinance of the Duchy of Württemberg ${ }^{12}$, where he himself was active. The Carniolan Provincial Estates, by whom Trubar was nominated preacher and superintendent in Ljubljana in 1560 (he assumed the position in 1561), entrusted him with the preparation of the church ordinance. In July 1563, the manuscript was ready for

\footnotetext{
7 Paulsen F. Geschichte des gelehrten Unterrichts auf den deutschen Schulen und Universitäten vom Ausgang des Mittelalters bis zur Gegenwart - Mit besonderer Rücksicht auf den klassischen Unterricht: in 2 Bdn. Bd. 1. Leipzig, 1919; Engelbrecht H. Geschichte des österreichischen Bildungswesens...; Seifert A. Das höhere Schulwesen - Universitaten und Gymnasien. P. 197-373.

${ }^{8}$ Loserth J. Die protestantischen Schulen der Steiermark im sechzehnten Jahrhundert; Vidmar T. Das protestantische Schulwesen in Krain, in Kärnten und in der Steiermark.

${ }^{9}$ Loserth J. Die protestantischen Schulen der Steiermark im sechzehnten Jahrhundert; Vidmar T. Das protestantische Schulwesen in Krain, in Kärnten und in der Steiermark; Engelbrecht H. Geschichte des österreichischen Bildungswesens...

10 Vidmar T. Das protestantische Schulwesen in Krain, in Kärnten und in der Steiermark.

11 Trubar P. Cerkovna ordninga - Slowenische Kirchenordnung, Tübingen 1564: in 2 Bdn. Bd. I: Text. München, 1973.

12 Paulsen F. Geschichte des gelehrten Unterrichts...
} 
publication. As it was impossible to expect that the local sovereign would in fact officially authorize the ordinance, it was supposed to be printed as Trubar's private work and introduced in parishes with the approval and support of the Protestant Provincial Estates. The very printing and publication caused considerable trouble; furthermore, the book was in circulation only from September or October to December of the same year when the Habsburg ruler ordered all copies to be confiscated and Trubar banished from the land. Nevertheless, the awareness of the order survived: as late as 1575 Trubar was still drawing the attention of priests in Carniola to it ${ }^{13}$. Trubar's Cerkovna ordninga was the first Protestant church ordinance in Austrian hereditary lands ${ }^{14}$.

Part of the Cerkovna ordninga was intended for schools, and in it Trubar expressed his views about the organization of schools in the land. The introduction to the chapter is quite similar to contemporary German school ordinances, and the text emphasizes the need for establishing and maintaining schools, which - according to Luther's demands was the responsibility of the secular authorities. However, there are considerable differences in the actual proposals concerning schools in the land, their organization, the level of education they provided, and the curricula. All this is absent from the Carniolan ordinance. Trubar was evidently aware of the existent situation and refused to write about unachievable ideals ${ }^{15}$. His "plan" for the organization of schooling in general foresaw schools in every town, borough or parish - German and Latin schools in towns and boroughs, and parish schools where pupils were supposed to be taught in the Slovene language ${ }^{16}$.

However, Trubar was not able to organize schooling as he had no authority for it. Unlike in the German lands, the Provincial Estates could not take such important decisions without the approval of the local sovereign. It is also noteworthy that during Protestantism in Carniola, the Provincial Estates always complained about the financial means for the development of education ${ }^{17}$. Concerning the payment of "educated teachers", "devout disciples" and "loyal preachers", Trubar says, "the Church is obliged to pay for them"18. As every worker deserves to be paid, so do the servants of the Church, including teachers, who should be given the remunerations of the Catholic prelates.

In Ljubljana Protestants also felt the need for their own schools and education, so following the German example - they decided to set up their own Provincial School (Adam Bohorič called it schola procerum, and Nikodem Frischlin - Landtschafft Schüell), which was not supposed to be elementary, and was open only to boys with a certain knowledge of the Latin language. A large share of credit for the actual foundation of the school goes to Primož Trubar, who - although he lived and worked in Württemberg - was personally involved in its establishment ${ }^{19}$. In a letter to the Württemberg Duke Ludwig from

${ }^{13}$ Elze T. Primus Trubers Briefe - Mit den dazu gehörigen Schriftstücken gessamelt und erläutert. Stuttgart, 1897. P. 523-550; Schmidt V. Pedagoško delo protestantov na Slovenskem v XVI stoletju. Ljubljana, 1952; Rupel M. Trubarjeva skrb za študente // Razprave razreda II za filološke in literarne vede. 1965. No. VI. P. 5-36.

14 Weismann C. Conclusion // Trubar P. Cerkovna ordninga... P.XXVIII-XXXII.

15 Vidmar T. Nastajanje novoveške stopenjske šolske strukture.

16 Trubar P. Cerkovna ordninga... P. 78-79.

17 Schmidt V. Pedagoško delo protestantov na Slovenskem v XVI. stoletju; Rupel M. Trubarjeva skrb za študente.

18 Trubar P. Cerkovna ordninga... P. 79.

19 Vidmar T. Nastajanje novoveške stopenjske šolske strukture. 
1585, Trubar among other things writes that in Ljubljana "all pupils from Latin, German and Slovene schools" joined the funeral processions ${ }^{20}$.

When in 1562 Trubar presented to the Carniolan land authorities the proposal of the Württemberg Duke Christopher - namely that two scholarships or stipends were available in Tubingen - they started looking for suitable candidates for university studies, but "it turned out that there were no students ready for higher education" 21 . Consequently, Trubar had an idea that Ljubljana needed a secondary school, which - among other things would prepare students for university studies. Therefore, in 1563, the Provincial Estates employed Master Lenart Budina as rector and the only teacher of the school which remained a one-class school until 1566 when Trubar and the Provincial Estates decided to nominate Adam Bohorič rector ${ }^{22}$. For the needs of the school Bohorič wrote the School Ordinance (Ordo scholae), the second redaction of which was adopted in 1575 (the first was written and submitted to the authorities soon after Bohorič assumed his position in 1566, but the Provincial Estates were unwilling to adopt it), and remained in force until 1584.

Organization of the Provincial School in accordance with Bohoričs School Ordinance (1575). Bohoričs school had four classes (classes), of which the first was divided into three decuries (decurias). In relation to the first class it is interesting to note that Bohorič foresaw special classes for those who were supposed to learn only German ("if there are any" as he wrote $)^{23}$. What this is supposed to mean is unclear as nothing similar can be found in the orders of corresponding German schools. Schmidt believes that the decury was "intended for pupils who did not plan to continue their education in higher classes..., i.e. the sons of wealthier parents, especially merchants" 24 . This is quite possible, although no other Protestant school - state or provincial - had the German language in the curriculum. It is therefore possible that German (in addition to mathematics, the curriculum consisted of German, writing and catechism) was intended for Slovene pupils who did not know the language before they came to school. Although there were probably only a few of them, Bohorič's plan is indicative of the contemporary situation in Carniola.

During his study in Wittenberg, Adam Bohorič was a student of Philipp Melanchthon, one of the most prominent German Protestant scholars ${ }^{25}$. Melanchthon must have influenced Bohorič who - if he had not been well acquainted with the situation in Carniola, i. e. with structure of the population - would have copied one of the plans devised by his teacher and would have left German out as a subject ${ }^{26}$. This opinion is also supported by the literature which Bohorič prescribed for the decury: among the textbooks, there were no Latin books, only the German and Slovene catechisms ${ }^{27}$. It is also possible that the above-mentioned decury of the first class, to which Bohorič gave careful consideration, was in fact the elementary level of the school, while the other two decuries were the secondary - Latin - level.

${ }^{20}$ Rupel M. Trubarjeva skrb za študente. P. 20.

21 Ibid. P. 11.

22 Elze T. Die Rectoren der Krainischen Landschaftschule in Laibach während des XVI. Jahrhunderts // Jahrbuch der Gesellschaft für die Geschichte des Protestantismus in Oesterreich. 1899. No. 20. P. 117-153; Vidmar T. Das protestantische Schulwesen in Krain, in Kärnten und in der Steiermark.

${ }^{23}$ Bohorič A. Ordo scholae procerum in Carniola revisus anno 1575 // Schmidt V. Pedagoško delo protestantov na Slovenskem v XVI. stoletju. P. 190.

${ }^{24}$ Schmidt V. Pedagoško delo protestantov na Slovenskem v XVI. stoletju. P. 156, note 13, p. 124-125.

25 Bohorič A. Arcticae horulae succisivae. Maribor, 1987. P. 21.

26 Vidmar T. Das protestantische Schulwesen in Krain, in Kärnten und in der Steiermark.

27 Bohorič A. Ordo scholae procerum in Carniola revisus anno 1575. P. 190. 
The division of the first class into the next three decuries, of which two were using the Slovene catechism by Sebastijan Krelj, and one the Latin by Johannes Brenz is also of interest but difficult to understand. It is indeed quite peculiar, considering that the first decury, in which there were pupils learning the alphabet (alphabetarii), used the Latin catechism; the second, in which pupils were learning to spell and form words, used the Slovene and the Latin catechisms and the Latin gospels, while the third, in which they were learning only German, used the German and Slovene catechisms and the German gospels ${ }^{28}$.

In the second and the third classes it was forbidden to speak Slovene (so that the pupils gradually got used to German), and in the fourth class only Latin was allowed (only with special permission were pupils allowed to utter a word or a phrase in German ${ }^{29}$. Third-class pupils were called "Donatists" (the main grammar book was that of Donatus), and they also studied arithmetic and music. In the fourth - final - class, the pupils were called "grammatists"; they read Cicero's letters, Vergil and Terence, studied arithmetic, music and the basics of $\mathrm{Greek}^{30}$.

Bohorič also envisaged additional lectures for more talented pupils, which should be held either before or after the regular ones. The pupils studied the basics of dialectics and rhetoric, read Demosthenes's speeches, were acquainted with fundamental notions of natural and moral philosophy (naturalis et moralis philosophia), theology and the basics of geography (geographiae introductio). Whoever was interested could also study basic astronomy (sphaerica doctrina $)^{31}$. The above-mentioned subjects qualified the Ljubljana Provincial School as a secondary school and placed it in the same category with larger Protestant schools - the so-called gymnasia ${ }^{32}$. However, formally, if not actually (as will become clear later), the level of knowledge acquired was rather modest. The purpose of additional lectures was for the pupils "to be ready for these arts [artes] and to be able to understand them faster and more thoroughly when studying at universities [in Academia]"33. To advance into a higher class (ex inferioribus classibus gradatim ad superiores), pupils had to take two examinations a year before a jury (praesentibus inspectoribus) (on St. George's and St. Michael's days).

The School Ordinance also contained provisions for teachers or assistants to rector, as Bohorič referred to them. The fourth class was taught by the rector (ludirector), and the remaining three classes - by three teachers or assistants to rector (hypodidascali). They had to pay attention to their students' behavior and actions and be especially careful to notice the differences in the pupils' talent (dissimilitudo ingeniorum). Teachers were instructed to punish pupils as little as possible ${ }^{34}$.

Organization of the school in accordance with Frischlin's School Ordinance (1584). In 1582, Bohorič retired from the position of rector of the Ljubljana Provincial School (and was at the same time appointed the superintendent of the school); Doctor Nicodemus Frischlin, university professor from Tubingen, filled the vacant

28 Ibid. P. $190-191$.

29 Ibid. P. 193.

30 Ibid. P. 191-195.

31 Ibid. P. 194-195.

32 Engelbrecht H. Geschichte des österreichischen Bildungswesens...; Seifert A. Das höhere Schulwesen - Universitaten und Gymnasien. P. 197-373.

33 Bohorič A. Ordo scholae procerum in Carniola revisus anno 1575. P. 195.

34 Ibid. P. 196-197. 
post $^{35}$. Frischlin wrote a school ordinance too but had even more difficulty in having it adopted than his predecessor. The Provincial Estates finally adopted and approved of the third variant of the order in 1584, after Frischlin had almost given up all hope ${ }^{36}$. In comparison with Bohorič's, Frischlin's School Ordinance (Die Schüell Ordnung) was written more in the style of German Protestant school ordinances.

Pupils had to pay school fees (Schuellgeldt), the amount of which depended on the financial situation of their parents (from one to four florins annually). Pupils in higher classes had to pay higher school fees than those in the lower. The fees were paid quarterly ${ }^{37}$.

Frischlin also divided the classes into decuries: the first class was divided into four decuries; the second to fourth classes were divided into two decuries; and the fifth class was not subdivided ${ }^{38}$.

The rules concerning discipline were quite stern as they prescribed mostly corporal punishment for all kinds of breaches of discipline ${ }^{39}$. In every decury and in every class, teachers were instructed to have their informer (Coricaeus, haimblicher Aufmerckher), who was to watch over his school-friends at school, in church and in the streets. Every class (apart from the first) also had to have a wooden jackass (asinum) which was given to the pupil with poorest performance in Latin. Whoever received it last during the day, was given a beating the following day ${ }^{40}$.

In the fourth class, pupils started reading Vergil and Terence, and were taught the elements of Greek, in the fifth class they studied dialectics and rhetoric, continued reading Vergil and Terence and studying Greek. Arithmetic was taught from the third class onwards ${ }^{41}$.

Nicodemus Frischlin remained rector of the school until 1584 when he came into conflict with the Provincial Estates and was forced to resign and leave the town. As he could find no teaching position in the land, he returned to Tubingen, Germany ${ }^{42}$. The former rector of the Klagenfurt Provincial School, Master Jakob Präntelius (Prentl), to be followed again by Bohorič (until July 1598), filled the vacated post. The last rector of the school, who held the position for only three months, was Master Engelbert Engel from Wittenberg ${ }^{43}$.

Closure of the Ljubljana Provincial School. On 30 October 1598, the land sovereign, Archduke Ferdinand II of Habsburg (he became later also the Holy Roman Emperor), issued a decree ordering all Protestant preachers and teachers to leave Ljubljana by sunset ${ }^{44}$. This was the end of the Ljubljana Provincial School.

${ }^{35}$ Elze T. Die Rectoren der Krainischen Landschaftschule in Laibach während des XVI. Jahrhunderts. P. 117-153; Vidmar T. Das protestantische Schulwesen in Krain, in Kärnten und in der Steiermark.

${ }^{36}$ Schmidt V. Pedagoško delo protestantov na Slovenskem v XVI. stoletju.

37 Frischlin N. Die Schüell-Ordnung // Schmidt V. Pedagoško delo protestantov na Slovenskem v XVI. stoletju. P. 205.

38 Ibid. P. 211-217.

39 Ibid. P. 209-211.

40 Ibid. P. 221-222.

${ }^{41}$ Ibid. P. 216-217.

${ }^{42}$ Schmidt V. Pedagoško delo protestantov na Slovenskem v XVI. stoletju; Vidmar T. Das protestantische Schulwesen in Krain, in Kärnten und in der Steiermark.

43 Elze T. Die Rectoren der Krainischen Landschaftschule in Laibach während des XVI. Jahrhunderts. P. 117-153; Vidmar T. Nastajanje novoveške stopenjske šolske strukture.

${ }^{44}$ Vidmar T.: 1) Nastajanje novoveške stopenjske šolske strukture; 2) Das protestantische Schulwesen in Krain, in Kärnten und in der Steiermark. 
During its entire existence, the Ljubljana Provincial School was faced problems, which schools in the lands ruled by Protestant rulers did not encounter. Among other things, it did not have properly equipped classrooms, was understaffed and underfunded, and finally yet importantly, had to deal with the fact that its pupils were leaving it with rather modest knowledge. In the seventies of the $16^{\text {th }}$ century, Trubar wrote to the Carniolan authorities asking them not to send to Tubingen and other places the young men who had previously "not acquired knowledge of all grammar, of principles of dialectics and rhetoric, because in that case, they should acquire these arts by private teachers with great expenses" 45 .

Unfortunately, the Ljubljana Provincial School existed for too short a time to develop its full potential; because of the victory of the counter-Reformation in Carniola it was forced to close its door even before it was consolidated and out of its troublesome initial phase.

\section{Secondary Education in Carinthia - Klagenfurt}

Situation in the $16^{\text {th }}$ century. In 1579, representatives of the ten Carinthian towns and eight boroughs in the provincial Diet decided to adopt the above-mentioned Bruck (religious) Pacification, which meant they agreed with its content. The larger part of the land thus adopted Protestantism, against the will of the land ruler (Archduke Charles II Francis of Habsburg) ${ }^{46}$.

Protestant education in Carinthia is very poorly documented; allegedly, in the $17^{\text {th }}$ century the Carinthian Estates "became so Catholic" that they destroyed all evidence of their Protestant past ${ }^{47}$. There were quite a few schools in Carinthia, but only the Provincial School in Klagenfurt was comparable to German Protestant gymnasiums. It was also the only institution preparing students for university studies ${ }^{48}$.

In 1579, the Klagenfurt town council founded a boarding school for poor, but talented children from the town or rural areas. It was intended to prepare pupils for the job of municipal clerks, and upon enrollment, the parents or custodians had to sign a document stating that after the graduation boys would enter the civil service. If it later would turn out they were not able enough for schooling or for the job, they would have to pay back the schooling fee. At the beginning, the school accepted ten children (part of the necessary finances was gathered through voluntary contributions), but in 1586, the number was halved due to lack of money ${ }^{49}$.

The school, which was perhaps a former Latin school, and was first mentioned in this function in 1560, was called "Nobility School" (die adelige Schule) or "College of Wisdom and Piety" (collegium Sapientiae et Pietatis), but also "Provincial School" (schola provin-

45 Rupel M. Trubarjeva skrb za študente. P. 14.

46 Baum W. Kollegium, Lyzeum, Gymnasium; Vidmar T. Das protestantische Schulwesen in Krain, in Kärnten und in der Steiermark.

47 Braumüller H. Zur Geschichte des Klagenfurter Schulwesens in der Reformationszeit // Carinthia I — Mitteilungen des Geschichtsvereins für Kärnten. 1924. No. 114. P. 13-14.

48 Baum W. Kollegium, Lyzeum, Gymnasium; Vidmar T. Nastajanje novoveške stopenjske šolske strukture.

49 Braumüller H. Zur Geschichte des Klagenfurter Schulwesens in der Reformationszeit. P. 13-31; Baum W. Kollegium, Lyzeum, Gymnasium. 
cialis $)^{50}$. The school in Klagenfurt was primarily intended for the children of the nobility (der Herren) and the land-owning classes (Landleute). As some of the landowners did not live in the town, they had to pay for the accommodation of their children ${ }^{51}$. In 1573, the School Ordinance was adopted for the school, but it has not been preserved ${ }^{52}$.

Organization of the school. The principal of the school was called praeceptor, and the other teachers were called collaboratores. In 1577, the title rector was first used for the principal. It is not known how many classes the Klagenfurt school had, but we assume there must have been from five to seven. The curriculum has also not been preserved, but we dare to suggest that it was comparable to the curricula of Provincial Schools in Graz and Ljubljana. The number of pupils was quite large, as in 1582, the school employed an eighth teacher to teach the lowest class. The Klagenfurt Provincial School also had a fencing teacher ${ }^{53}$.

In 1579, the Provincial Estates decided to co-operate with Carniola regarding the educational equality and began the process of unifying of the Provincial Schools, which also meant use of the same grammar and curricula in teaching. In 1580, Master Jakob Prentl became rector of the Provincial School (he occupied the position until 1585). He could hire and dismiss teachers, and no longer taught himself, as his predecessors were obliged to; the emphasis of his office was to watch over the school and the instruction. Eventually teachers and members of the land committee started filing different complaints about Prentl, and they were quite happy when - after Frischlin's resignation - he was appointed a new rector of the Ljubljana Provincial School. His successor in Klagenfurt was Doctor Philipp Marbach, university professor of theology in Heidelberg. In 1593, rectorship of the Provincial School was taken over by a well-known Protestant scholar Master Hieronymus Megiser (he occupied the position until the school was permanently closed in 1601) ${ }^{54}$.

The Klagenfurt Provincial School also comprised the so-called boys' school (Knabenschule, schola puerilis), an elementary or preparatory school, which - following the example of the Graz school - was intended exclusively for the children of the nobility and wealthier town families. The other children had to attend the town Latin school until they acquired the knowledge necessary for the enrollment in the first class of the higher level - the grammatical class of the Provincial School ${ }^{55}$.

Closure of the Klagenfurt Provincial School. On 1 June 1600, the land sovereign, Archduke Ferdinand II of Habsburg, issued a decree ordering all Protestant preachers and teachers to leave the land in ten days, but the Estates, preachers and teachers revolted against the decision. Consequently, in November of the same year, the Estates re-established Hieronymus Megiser as rector. However, Archduke's efforts for the recatholicization prevailed, the Estates were forced to give in, and the Klagenfurt Provincial School was closed on 13 April 1601. The teachers were paid compensation in the amount of an annual salary ${ }^{56}$.

${ }^{50}$ Braumüller H. Zur Geschichte des Klagenfurter Schulwesens in der Reformationszeit. P. 13-31; Baum W. Kollegium, Lyzeum, Gymnasium.

${ }^{51}$ Baum W. Kollegium, Lyzeum, Gymnasium.

52 Braumüller H. Zur Geschichte des Klagenfurter Schulwesens in der Reformationszeit. P. 19.

53 Baum W. Kollegium, Lyzeum, Gymnasium.

54 Ibid; Braumüller H. Zur Geschichte des Klagenfurter Schulwesens in der Reformationszeit. P. 13-31.

55 Braumüller H. Zur Geschichte des Klagenfurter Schulwesens in der Reformationszeit. P. 23.

${ }^{56}$ Baum W. Kollegium, Lyzeum, Gymnasium; Vidmar T. Das protestantische Schulwesen in Krain, in Kärnten und in der Steiermark. 


\section{Secondary Education in Styria - Graz}

Situation during the Reformation. The Styrian Church Ordinance was adopted in 1578, after the above-mentioned Bruck (religious) Pacification, and, as already said, part of it referred to schools as well. Schools had to be subordinated to the Church, and the rector - to the supervision of priests ${ }^{57}$. In Styria, Protestant Latin schools were established only where towns or boroughs belonged to the higher nobility, and they existed only until the nineties of the $16^{\text {th }}$ century. There is evidence about other schools as well but nothing is known of their organization ${ }^{58}$.

In 1580, in order to fight the Reformation, the land sovereign, Archduke Charles II Francis of Habsburg, issued an order according to which the religious liberty for the members of Augsburg confession was granted only to the nobility and landowners, i. e. members of the noble and knightly classes, but not to their bondsmen or the inhabitants of towns and boroughs. The situation became even tenser in 1587, when Archduke Charles issued a decree forbidding young people from his hereditary lands to study at foreign Latin schools and universities; he only allowed them to attend the Graz (Jesuit) University ${ }^{59}$.

School organization according to the School Ordinance by David Chytraeus (1574). The Graz Provincial School (Landschaftsschule, schola procerum) was originally intended for the nobility, but it soon started admitting the children of the middle classes and landowners as well. A great deal of the material related to the school has been preserved (decrees and letters of the Provincial Estates), but no copy exists of the original school ordinance written in 1574. In 1569, the town of Graz donated to the land of Styria the lot where the school was to stand, and the land had to promise that the school would also admit the children from the town "wealthy or poor, but capable of studying"60. The school relatively late - appointed the well-known Protestant professor of theology from Rostock, Doctor David Chytraeus, to write the school ordinance, which was approved by the Provincial Estates in 1574.

The Provincial School had three decuries for beginners, and four classes, of which the last was "public class" (classis publica); the teachers in the "public class" were called professors, and they taught theology, law and philosophy, so the classes were comparable to "public lectures" (lectiones publicae) at Protestant academic gymnasiums (e. g. in Strasbourg). The first three decuries were an integral part of the "boys' school" (schola puerilis), elementary level followed by four classes. In general, the Graz Provincial School was under a strong influence of Sturm's gymnasium in Strasbourg, particularly regarding the contents taught ${ }^{61}$.

The teaching staff consisted of professors, preceptors (praeceptores) and assistants (collaboratores). The rector, who was supported by the vice-rector, ran the school. In addition to the regular salaries, teachers also received money for wood and housing (if they

${ }^{57}$ Loserth J. Die protestantischen Schulen der Steiermark im sechzehnten Jahrhundert; Engelbrecht $H$. Geschichte des österreichischen Bildungswesens...; Seifert A. Das höhere Schulwesen - Universitaten und Gymnasien. P. 197-373.

${ }^{58}$ Engelbrecht $H$. Geschichte des österreichischen Bildungswesens... P.70; Seifert A. Das höhere Schulwesen - Universitaten und Gymnasien. P. 197-373.

59 Vidmar T. Nastajanje novoveške stopenjske šolske strukture. P. 131.

${ }^{60}$ Loserth J. Die protestantischen Schulen der Steiermark im sechzehnten Jahrhundert. P. 18.

61 Ibid. P. 32. 
did not live in the school apartments) and a certain remuneration for each additional service. In Graz, teachers also received a retirement benefit (gift of grace, which was also in practice in Provincial School in Ljubljana) and, if they were ill, the remuneration for medical treatment ${ }^{62}$.

Although the Provincial School was originally intended primarily for the children of the nobility and knighthood, it also started admitting the children of the town people after the agreement was reached between the town and the Provincial Estates. Eventually it also accepted the children of Protestant priests and teachers. A boarding house was set up for pupils coming from other Styrian towns, whose expenses were covered by scholarships. Stipendiaries were entitled to sustenance, clothing and, in the case of illness, free medical treatment. For admittance, a letter of recommendation from a landowner or some other important individual was needed. Every candidate had to take an entrance examination before a jury. Until the Bruck (religious) Pacification, the boarding school admitted only boys from Styria, and later also from Carniola and Carinthia ${ }^{63}$.

In 1577, the Provincial Estates of Styria wanted to employ Doctor Nikodemus Frischlin as a rector or professor, but the Provincial Estates of Carniola were quicker and appointed Frischlin rector of the Provincial School in Ljubljana. When he had to resign in 1584, he was no longer welcomed in Graz, where they had similar problems with their recent rector ${ }^{64}$.

From 1580 onwards, on the orders of the land sovereign, the Provincial School in Graz was no longer allowed to accept the children of the townspeople and was only open to the nobility. If the children of the lower classes continued their schooling, their parents would have to pay substantial fines ${ }^{65}$.

Organization of the school in accordance with the Reformed School Ordinance (1594). Due to external and internal problems, conflicts and lack of discipline the Styrian Provincial Estates decided to revise the existing school ordinance, and in March 1594, the Reformed School Ordinance (Reformierte Schuel-Ordnung) was adopted. In the very introduction, it was stated that the new order was being adopted because of discipline was lacking in the Styrian college (wegen zerfalnen schueldisciplin) ${ }^{66}$. The school was to have - as was stipulated in the first School Ordinance by David Chytraeus in $1572-$ three decuries of "boys' school" (scholae puerilis), followed by four classes, followed by a "public class" (publica classe); the organization was adopted at the assembly in Bruck by all three lands - Styria, Carinthia and Carniola ${ }^{67}$.

The school regulations foresaw 32 available places for the stipendiaries (stipendiaten). In accordance with the new school ordinance, the existing stipendiaries had to be examined and either admitted again or dismissed. School supervisors were supposed to hold a meeting (conventum scholasticum) once a month to evaluate the fulfilling of obligations of the rector, the public professors (professores publici) and the class teachers (classici praeceptores). The rector was obligated to visit the stipendiaries on Saturdays, when their leader (Ephorus) had to make a report about their conduct, knowledge, work in the school

\footnotetext{
62 Loserth J. Die protestantischen Schulen der Steiermark im sechzehnten Jahrhundert. P. 40-49.

63 Ibid. P. 51-56.

64 Ibid. P. 78.

65 Ibid. P.73.

66 Reformierte Schuel-Ordnung // Monumenta Germaniae Paedagogica. P. 155.

67 Ibid. P. 156-157.
} 
(in disciplina, studiis, moribus et legibus). Every Monday, the rector, together with a public professor, had to check the situation in all classes ${ }^{68}$.

The pupils who were accommodated in the college were only allowed to speak Latin with each other. They were forbidden to play card games or to dice (mit karten, wirfl oder dergleichen spilen), but they could go walking within the college walls at scheduled times. In the morning they had to make their beds and clean up their bedrooms. They also had to pay their school fees regularly - nobody should be admitted to the school without a guarantee of payment ${ }^{69}$.

In the first decury of the "boys' school" the boys learnt to read and write Latin and German and used Luther's German Catechism for the religious instruction. In the third decury, they began with Luther's Latin Catechism. In the first class (in prima classe), they studied Cicero's letters, Terence's comedies and Luther's Latin Catechism. In the second class, they started learning dialectics and rhetoric, read Cicero and Vergil, and acquired the basics of Greek. They used the Latin Catechism and Greek Gospels. In the third class, they continued reading dialectics and rhetoric, studied longer Cicero's speeches, Vergil, Isocrates and Greek. Third class students were obliged to attend public disputes and speeches. The fourth class, the so-called "public class" (quarta classis, quae publica dicitur), studied dialectics and rhetoric at a higher level, and even Aristotle's Organon and Ethics, as well as theology, Hebrew for theology students, law, mathematics and physics ${ }^{70}$.

Closure of the Graz Provincial School. The school started facing serious problems in 1585, when the Jesuits summoned to Graz in 1573 by the land sovereign (Archduke Charles II Francis of Habsburg) founded a university (Jesuit College was founded already in 1573) in order to "preserve the true and pure Catholic faith of our ancestors, unblemished and uncorrupted"71. The Jesuit university studies comprised liberal arts (artes liberales), philosophy and theology, but no law or medicine, as it was primarily supposed to serve sacred purposes and were not to compete with other universities in the Habsburg lands ${ }^{72}$.

On 28 September 1597, Protestant teachers and preachers in Graz were ordered to leave the town by sunset and the hereditary lands - in eight days. The students - mostly stipendiaries - left the school soon afterwards, and the Provincial Estates paid for their fare $^{73}$.

\section{Conclusion}

In each of the three Inner Austrian lands, the Provincial Estates tried to organize schooling formally, at least at secondary level. We tend to believe that the schooling of future scholars, teachers and preachers was only the first step in the efforts to raise the level of education of the population (in 1530, in a letter, or rather in a sermon, about the necessity of educating children Martin Luther himself demanded that even the boys not particularly talented should learn to read and write Latin). However, even before the first

\footnotetext{
68 Ibid. P. 159-161.

69 Ibid. P. 163.

70 Ibid. P. 164-166.

71 Loserth J. Die protestantischen Schulen der Steiermark im sechzehnten Jahrhundert. P.79.

72 Vidmar T. Das protestantische Schulwesen in Krain, in Kärnten und in der Steiermark.

73 Vidmar T. Nastajanje novoveške stopenjske šolske strukture. P. 133.
} 
phase of organizing schooling in the Protestant Inner Austrian lands could yield results, Protestant schools were closed, and teachers banished. Nevertheless, for each of the three lands - Carniola, Carinthia and Styria - the establishment of the Provincial School was the first actual opportunity for the foundation of a central institution providing not only elementary knowledge, but also higher levels of education partly comparable to the curricula of the faculties of arts. However, the question remains of how the above-mentioned schools would have developed in more favorable circumstances, whether they would eventually have turned into institutions of higher education (like in Strasbourg, for instance), and what implications this would have had for the development of elementary and secondary schooling in the three Inner Austrian lands, and above all in Carniola.

Unfortunately, at the end of the $16^{\text {th }}$ century, the development of the Provincial Schools was forcibly stopped, which is why they could not show conclusive results. Their organizational structure was still at the beginning of the development. In any case, the three Provincial Schools, despite their short-lived existence, played an important part in the development of humanistic education on the territory of modern Republic of Slovenia and the Republic of Austria.

\section{References}

Baum W. Kollegium, Lyzeum, Gymnasium. Vom “Collegium Sapientiae et Pietatis” zum Bundesgymnasium Völkermarkter Ring, Klagenfurt. Die Geschichte des ältesten Gymnasiums Österreichs. Klagenfurt, Kärntner Druck- und Verlagsgesellscahft, 1991, 407 p.

Bohorič A. Ordo scholae procerum in Carniola revisus anno 1575. Schmidt V. Pedagoško delo protestantov na Slovenskem v XVI. stoletju. Ljubljana, DZS, 1952, pp.189-201.

Bohorič A. Arcticae horulae succisivae. Ljubljana, Založba Obzorja, 1987, 331 p.

Braumüller H. Zur Geschichte des Klagenfurter Schulwesens in der Reformationszeit. Carinthia I - Mitteilungen des Geschichtsvereins für Kärnten, 1924, no. 114, pp.13-31.

Elze T. Primus Trubers Briefe - Mit den dazu gehörigen Schriftstücken gessamelt und erläutert. Tübingen, Litterarischer Verein in Stuttgart, 1897, 574 p.

Elze T. Die Rectoren der Krainischen Landschaftschule in Laibach während des XVI. Jahrhunderts. Jahrbuch der Gesellschaft für die Geschichte des Protestantismus in Oesterreich, 1899, no. 20, pp. 117-153.

Engelbrecht H. Geschichte des österreichischen Bildungswesens - Erziehung und Unterricht auf dem Boden Österreichs, Bd. 2. Wien, Österreichischer Bundesverlag, 1982, 462 p.

Frijhoff W. Grundlagen. Geschichte der Universität in Europa, Bd. II. München, C. H. Beck, 1996, pp. 53-102.

Frischlin N. Die Schüell-Ordnung. Schmidt V. Pedagoško delo protestantov na Slovenskem v XVI. stoletju. Ljubljana, DZS, 1952, pp. 203-224.

Loserth J. Die protestantischen Schulen der Steiermark im sechzehnten Jahrhundert. Monumenta Germaniae Paedagogica, Bd. LV. Berlin, Weidmannsche Buchhandlung, 1916, 217 p.

Paulsen F. Geschichte des gelehrten Unterrichts auf den deutschen Schulen und Universitäten vom Ausgang des Mittelalters bis zur Gegenwart - Mit besonderer Rücksicht auf den klassischen Unterricht, Bd. 1 . Leipzig, Veit \& Comp, 1919, 636 p.

Rupel M. Trubarjeva skrb za študente. Razprave razreda II za filološke in literarne vede, 1965, vol. VI. Ljubljana, SAZU, pp. 5-36.

Schmidt V. Pedagoško delo protestantov na Slovenskem v XVI. stoletju. Ljubljana, DZS, 1952, 224 p.

Seifert A. Das höhere Schulwesen - Universitäten und Gymnasien. Handbuch der deutschen Bildungsgeschichte, Bd. I: 15. bis 17. Jahrhundert - Von der Renaissance und der Reformation bis zum Ende der Glaubenskämpfe. München, C. H. Beck, 1996, pp. 197-373.

Trubar P. Cerkovna ordninga - Slowenische Kirchenordnung, Tübingen 1564, Bd. I: Text. München, Dr. Dr. Rudolf Trofenik Verlag, 1973, 168 p. 
Vidmar T. Nastajanje novoveške stopenjske šolske strukture. Ljubljana, Znanstveni inštitut Filozofske fakultete, 2005, $194 \mathrm{p}$.

Vidmar T. Das protestantische Schulwesen in Krain, in Kärnten und in der Steiermark. Klagenfurt, Österreichische Gesellschaft für Historische Pädagogik und Schulgeschichte, 2008, 55 p.

Weismann C. Conclusion. Trubar P. Cerkovna ordninga - Slowenische Kirchenordnung, Tübingen 1564, Bd. I: Text. München, Dr. Dr. Rudolf Trofenik Verlag, 1973, pp. I-XXXIV.

Статья поступила в редакцию 4 июня 2020 г. Рекомендована в печать 9 сентября 2020 г.

Received: June 4, 2020

Accepted: September 9, 2020 